\title{
WOMEN IN EDUCATIONAL LEADERSHIP FROM ISLAMIC PERSPECTIVES
}

\author{
Devi Pramitha \\ UIN Maulana Malik Ibrahim Malang \\ devipramitha@uin-malang.ac.id
}

\begin{abstract}
The capacity of women to become leaders has always been the main question questioned by various groups when the discourse on women's leadership develops in public, especially when debates are related to an Islamic perspective. For women who lead educational institutions, they must be able to lead the institution, be responsible for the achievement of the institution, and are also expected to become leaders and innovators in the institution. Besides that, one must also have leadership skills and human relations and leadership skills that are good to apply the model according to its characteristics, because the real success of an institution lies in the efficiency and effectiveness of the appearance of a leader. This study uses a qualitative approach to literature study methods. From the results of the author's analysis, it can be concluded that: (1) Women have the spirit, skills, and qualities that are not less than men; (2) Requirement for an educational leader is that the educational leader must be able to lead the organization/ institution, is responsible for the achievement of the organization/ institution, is also expected to be leaders and innovators in organizations/ institutions; and (3) both one's biological factor that men and women are not the main requirements in educational leadership.
\end{abstract}

Keyword: Educational Leadership, Islamic Perspective, Women's Leadership

\section{INTRODUCTION}

In the book Megatrends 2000, there is a chapter entitled "The I990's" Decade of Women in Leadership" written by John Naisbitt and Patricia Aburdene, they predict that in the 1990s and away into the 21st century, the women's role increases. The most interesting thing is that opportunities for women to become leaders are greater. Although Naisbitt and Aburdene are making predictions based on the realities and historical experiences of women in the United States, it does not mean that Indonesian will not be affected since, in this globalization era, the world society is affected each other. Several phenomena that occurred in the Western will affect Indonesia (Al-Hibri, dkk, 2001).

When we talk about leadership, it is associated with the power aspect, whereas the sense of leadership can be interpreted more widely and not limited to the power in the political area. Marwah Daoed suggests that leaders should be available in various fields and levels. There are leaders in 
the world of ideas, and some are in the real world (Tan, 1991). Furthermore, leadership sources are more diverse so that more opportunities for women to achieve it.

Nowadays, women's leadership became a public issue that is always discussed and has provoked polemics and debates between the pros and cons to women as state leaders, despite the recognition of basic human rights that appears to already have a significant increase in various parts of the world. This recognition is applied also for the rights to be equal to men. Moreover, the presence of women leaders in education is still a minority, as evidenced by the lack number of female Principals, female chiefs, or heads of Islamic Education Institute, the small number made the effectiveness of women in education remains a question. Even though the leadership and active role of women in the public sphere is one of the main ideas in the discourse of equality and gender justice (Naily, 2008).

The majority of the population in Indonesia is Moslem, but as recognized from the past until today, the implementation of democracy in the true teaching in Islam was still quite daunting. It is seen from the inequality of women's social position as still widespread. Although Megawati Soekarno Putri has been elected to lead this country, it is still even generated a lot of controversies. Parties disagreeing with thinking in cultural aspects were not willing to accept a woman as a leader. On the other hand, the sympathizers claim that the event indicating a consciousness of the nation towards gender consciousness regardless of the quality of the woman is raised after the election of Megawati.

he mission of Islam is to free human beings, both men and women from the shackles of oppression, backwardness, and injustice. There are many texts of Al-Quran and Hadith that proclaim these. However, it often misleads to refraction gender as if the text is to favor a particular gender. Moreover, religious texts are only partially understood, so that distortion of interpretation as if Islam discriminates against a particular gender (Diana, 2008). Wahbah Al-Zuhaili says that men as a condition of a leader are the consensus of Fiqh scholars. It is based on the hadith of The Prophet that narrated by Abiy Bakrah, who outwardly showed that a nation will not prosper if led by a woman.

This Hadith is understood as a sign that women should not become a leader in any matters. Therefore many scholars view women as not allowed to lead. They responded to this Hadith as the Shari'a of Islam that becomes a universal standard, regardless of the aspects related to the Hadith. Such is the capacity of the Prophet when he said the Hadith and condition of the background of Hadith as well as the social setting that surrounds a Hadith (Diana, 2008). 
In the history of al-Bukhari that marfu 'and authentic quality no. 2232 stated that:

From 'Abd Allah ibn' Umar that he heard Rasulullah. said, "You all are leaders and will be questioned about his leadership, a man is a leader in his home and his leadership will be questioned, a woman is a leader in the home of her husband and his leadership will be questioned, an aide to the leader of the common property of his master, and will be questioned leadership", 'Abd Allah ibn Umar said, all that I heard from the Prophet, and I think the Prophet also said, "and a man was the leader of his father's treasure, and he will be questioned his leadership, all you are the leader and his leadership will be questioned.

Hadith above that is on the historical context of the Arab community divides the domestic duties for women and the public for men. Each part must take responsibility for his dependents. But in modern society, these roles are not evolving, as women and men alike are demanded to be equal in both domestic and public domains. Responsibilities of the two domains are flexibly located at both. The development of science and technology can support a shift domestic role of public-together between men and women. Thus, whoever it is either male or female even eligible to become a leader (Anwar, dkk, 2010).

For example, in education, the leader of educational institutions has a very big role because he is a coordinator, determine the direction and policies towards educational institutions at large. As a manager of institutional education units, leaders are required to always improve the effectiveness of their performance. To achieve effective quality education, officials and all stakeholders must work together with the full cooperation of cohesion in all respects.

\section{DISCUSSION}

\section{Leadership from The Islamic Perspective}

Educational leadership is an essential part of an educational organization, even a very urgent matter in the course of educational organizations to achieve educational goals that are institutional and national levels. Bush (2008) Bush in this framework states that outstanding leadership has invariably emerged as a key characteristic of outstanding schools. There can no longer be a doubt that those seeking quality in education must ensure its presence and that the development of potential leaders must be given high priority.

Also in the world of education 'like or dislike' to know the advantages and disadvantages of educational leadership figure. Therefore, education is a social institution that offers services that are intellectual, affective, 
psychomotor, emotional, and even spiritual self-learners fostered in existence for the survival of human civilization. Thus, the ideal leadership is leadership that exemplified the Prophet Muhammad as the leader of multidimensional, religious leaders, warlords, and also as a leader in education (Baharuddin dan Umiarso, 2012).

Islam is a religion that is concerned about leadership. This is because Islam considers man as basically the leader, which is the representative of Allah on earth, or what we refer to as khalifatullah fi al-ard, as written in the Qur'an. Al-Baqarah: 30, namely:

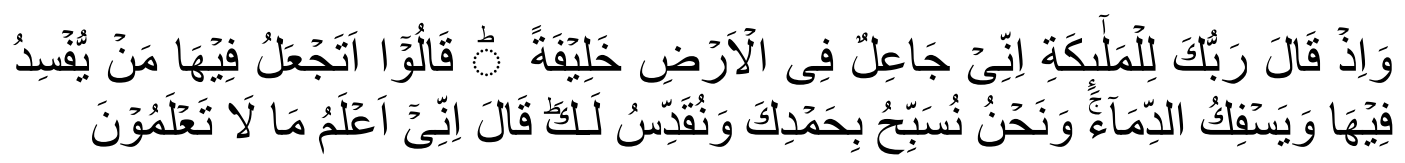

"And when your Lord said to the angels: "That I am making in the earth a leader." They said: "Do you make in it, who corrupts in it and sheds the blood, and we praise with Your praise and we holiness to You." He said: "I know what you do not know".

In the authentic hadith, the Prophet also emphasized that every person is a leader: "Every time you are a leader, and be responsible for the people he leads; an imam (head of state) is the leader and be responsible for the people they lead." (Narrated by Bukhari from Ibn Umar companions).

In the Islamic concept, leadership can be defined as a concept of interaction, relationships, authority, influence activities, directing and coordinating both horizontally and vertically. Which then in management theory, functions as a leader of planners and decision-makers (planning and decision-maker), organizer (organization), leadership and motivation (leading and motivation), monitoring (controlling), and others (Fakih, dkk, 2001). It can be concluded that the leadership in the Islamic perspective is an activity or the ability of others to direct and motivate the behavior of others, and there is a corporation following the values of Al-Quran and Al-Hadith to achieve the desired objectives together.

Some terms are commonly used in Islamic literature in terms of leadership, namely: the caliph, ulul amri, priests, and malik. Caliph as defined by Ibn Khaldun had two lawsuits that benefit the world and the hereafter. On one hand, the leader in the replacement of leadership gets a mandate from heaven after the Apostles died. While on the other hand, leaders who set the man on earth, of course, rationality leaders must walk the objective conditions on earth (Baharuddin dan Umiarso, 2012).

The term of ulil amrican be interpreted as the powers and rights owners to order something. Someone who has the power to order something 
meaningful in question has the power to regulate and control the situation (Salim, 2004). In the Qur'an Surah an-Nisa ': 83 identifies the existence of leadership that is strongly associated with the leadership of God and His Messenger so that after the Prophet's death ulil amri as a reference in dealing with the problem as well as the duty to always be obeyed.

Furthermore, the priest said that the roots of the letter hamzah and mim, both the letter has many meanings, among them is the principal, where again, prayers, time and. The scholars define the word priest as any person can be followed and displayed next to the various problems. As for the term, al-Malik means a person who has the authority to order something and ban something in connection with a government (Zakariyya, 1989).

Differences in terms of leadership in Islam and that proposed by the theorists of leadership is that leadership in Islam is to carry out the functions of the human as a vicegerent on earth. It also runs a foundation in leadership in Islam must be based on the Qur'an and hadith. So the core of the leadership of the terms above equation on the domain containing lead or mobilize many people to achieve a common goal which is blessed by Allah SWT. That is, these terms lead to the devotion of a man to his Creator in the world and reaching happiness hereafter. In this case, the direct leadership of the Islamic leadership principles of Islam, which is trustworthy, fair, shura (consultation), and amr doing good and avoiding evil that must be applied in leadership behavior.

\section{Women's Leadership from An Islamic Perspective}

The discourse of women in Islam has always received a very serious concern. The role and function of women become an emphasis. Basically, women and men seated in the view of Islam are the same in law. This description is very apparent in surah An-Nisa 1:

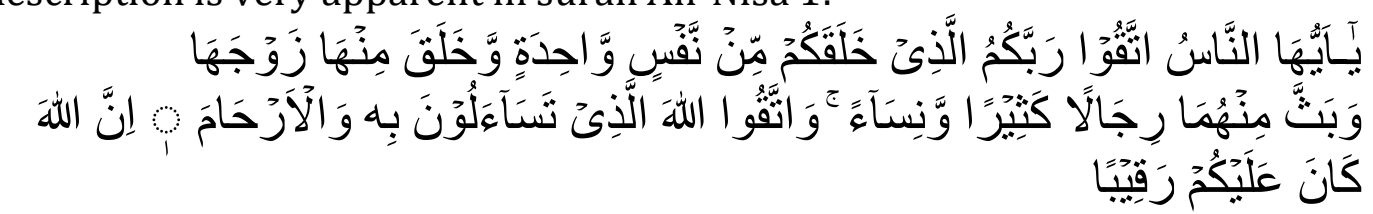

"You, you the people, fear and obey your Lord who created you from oneself and He created from it its spouse, and He scattered from them many men and women, and fear and obey God who you ask each other to each other with Him, and the uteruses, that God is on you observing"

However, in the other perspective, women are objects that should be led by men, as it is written in An-Nisa: 34. However, it does not mean women do not get a decent position. Women within certain limits instead become a 
milestone in the State, with its participation in educating their offspring. Besides the agent role in the intellectual and glory, women also play an important role in the process of proselytizing Islam. Women like Asma bin Abu Bakar are an example of how a woman can give a very significant contribution to the prophet's move strategy.

Women's capacity to be a leader has always been the main things questioned by various groups when women's leadership discourse develops in public, especially when the debate is linked to the Islamic perspective. Whereas in the discourse of leadership, men capacity issues are never raised as a key issue. As there is already an image that has identified the 'leadership' with 'men'. The image is then formed in a society based on religious beliefs and cultural influences that make women weak leadership image, as well as building the image of women as being 'led' and not 'leading'. As a result, many women have become increasingly alienated from leadership positions in the various public domain because it was already imaged that they cannot lead.

Women's leadership is a hot issue today. The scope of the discussion stems from the order of Shariah that gives barrier signaled a hadith which says that society will not prosper if given to women's leadership. According to Qardhawy (1997), this hadith is authentic because it is narrated by Abu Bakrah which was later quoted by Bukhari. While the hadith narrated by Bukhari is included the authentic hadith. While considerations of honor, there is a textually understood, or understood contextually. Textual understanding would conclude that the law of women being head of government is haram. While contextual understanding, that the hadith relating to the appointment of a woman to be a leader even though the surrounding Persian there are many adequate leaders, simply because the law requires such royal.

Jumhur scholars agree on the prohibition of women holding power in al-wilayatul-kubra or al-imamatul-uzhma (supreme leader). Where women's role as supreme leader in government affairs. Because in the hadith matan includes the word "Wallu Amrahum" (The Reign You All), which is interpreted as the Caliph of Islam in the political system. Thus giving scholars jumhur prohibition on women. Almost classical scholars consider it necessary to draw attention to become caliph rights are the rights of men, not women. This is expressed both by Al-Ghazali, Al-Mawardi, Ibn Taymiyyah, Ibn Khaldun. But within the limits of leadership in a particular field, who are not thorough in society, women are entitled to it, as the prosecutor, education and even become ministers (Qardhawy (1997). 
Whereas the aspects related to the Prophet and the conditions of background the Hadith have an important position in the understanding of Hadith. Allah says in QS. An-Nisa': 34

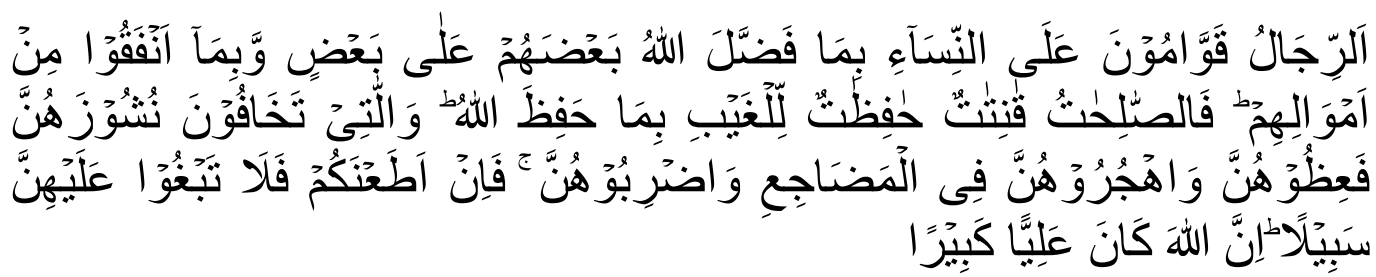

"The man is a leader for women, because God has preferred some of them (men) over others (women), and because they (men) has spent most of their possessions. Because it is so virtuous woman, who is obedient to God again when her husband did not maintain themselves there because God has been to maintain (them). Women that worried about nusyuz, so advice them and be separate them in their beds and beat them. Then if they follow you, so don't be looking for a way to troubling. Surely Allah is most high, most big"

The verse is often used as an excuse so women shall not be allowed to take the lead. The classic mufassir uses this verse as the legality of normative leadership of men over women in the household or in the broader aspects with the reason women not being able to maintain their honor. This becomes a question of whether the woman could keep her honor as a Principal and even giving a positive impact in advancing the educational institutions. In a patriarchal society, leadership is always identified with men, while women are not allowed to serve as a leader in any field, even in the field of education such as being a Principal. The fact remains that the effectiveness of leadership is not determined by the gender of the ruling, but largely determined by the characters, quality, and behavior of the leader. In nature, the essence of leadership lies in the moral, qualities, and capabilities.

In terms of women's leadership maybe we should reflect on thoughts expressed by Toety Herati Noerhadi that there is a need for a redefinition of the meaning of leadership. They said: "The concept of leadership style is gaining more understanding that man must be ready to experience such redefinition of leadership by women is perceptively possible." Furthermore, Toety said that the Indonesian people who give a high place on the image of motherhood will also sustain female leadership (Tan, 1991). If so in the future of Indonesia can be expected to have a woman leader with wisdom and prudence 


\section{Women In Educational Leadership}

Women as a formal leader at first many doubted, given the appearance of different women to men, but these doubts can be overcome with skill and achievement. In the leadership well done by women and men have the same goals just different in terms of purely physical, as told Kimbal Young (in Kartono, 1983: 40) that:

"Leadership is a form of domination that is based upon personal capabilities that could encourage or invite others to do something; based on acceptance by the group, and has special expertise appropriate for the situation"

Leaders who are in the formal organization will have power management based on the principles of management as well so that its power is not connected with the institutional and personal traits, for example, a woman who became head of the school, then subordinates either teachers or administrative staff is not subject to her personally but to her leadership, on because she was as formal leaders. It is important to assess that the leadership of an emerging and can align themselves with men if the person concerned requires the achievement.

In education, Goldring and Chen (1994) reported that women in the United Kingdom and wherever most women only take part in the teaching profession, but there are relatively few and far who have important positions authorities in many secondary schools, colleges, and local administration education. So that the phenomenon of women's leadership in education has been the main attraction for further inspection. Studies conducted by Coleman (2000) suggest that the principal and the other female senior managers in England and Wales indicated they are likely to behave transformative and participatory leadership model. Other studies headteachers and principals and women in the United States, United Kingdom, Australia, New Zealand, and Canada showed that women managers perform work in a cooperative and empowering colleagues and teamwork effectively functioning (Blackmore, 1989; Hall, 1996; Jirasinghe and Lyons, 1996). Another result of the study conducted by Jirasinghe and Lyons, (1996) describes the personality of women leaders as someone more outgoing, democratic, caring, artistic, be kind, careful and conscientious, compassionate and cautious. Besides, they tend to be team worker figures, complete and perfect. They also identify themselves and perceive themselves as being more rational, relaxed, tough-minded, active, and competitive.

The obstacles for women to become education leaders there are two parties, namely the individual women who engaged in the world of education and the educational institution itself. The first constraint, there is the human 
resources and social structures in the educational institutions that have a gender perspective. There is an impression 'on the average' that could compete only men. Besides, there is also a culture that is put men in leadership. So sometimes it is not because women do not want to be a leader, but a culture that makes it difficult for women to lead forward. Therefore, if the social structure and culture in the world of education is not modified to provide greater opportunities to women then it is difficult for women to become leaders in education.

Other constraints exist in most individual women who lack confidence due to raised in a patriarchal society, which is a social system that places men as the primary authority figure is central to social organization. The women much earlier had the mindset that has been established that women do not need to lead and improvise career. So they tend to give up and do not want to seem pushy or 'begging' position. However globally, acknowledged there were some obstacles in women's leadership issues in education. Glass ceiling, the restrictions for women in academic promotion, the chilly climate in the process of academic women feel discomfort in the academic environment, and leaking pipelines or declining representation of women in some areas of academic life.

What about the professional identity of women in educational leadership? At the annual conference of the Australian Association Forum for Education Research (AARE Annual Conference), May 3-7, 2000, Jill Blackmore and Judyth Sachs, conduct research by exploring new issues concerning women and leadership in an era of restructuring throughout the 1990ies. From the interview that they did with a group of women who occupy leadership positions or have aspirations to occupy such a position, also with the woman who became the informal leader at school, university or college found some interesting phenomena, such as 1). There are individual differences (distinct differentiation) of the sense of belonging, commitment to the organization, and motivation depends on the presence in the organization. 2). Studies at many universities, colleges, and schools continue to prove that women are moving into the world of leadership at middle management and executive levels are mainly due to coincidence rather than deliberate design, and more based on collateral rather than potential performance. Their entry into the world of leadership is based on substantive professional expertise as an educator and the emotional aspects of labormanagement as change agents.

Women's leadership in professional education institutions work is guided by the properties of professionalism. Professionalism operates as an occupational strategy, defines the input and has negotiating power, and gain reward for his expertise. Those who fall into this category were able to 
implement the organization's strategy, sharpen the pattern of authority, able to position themselves and create a coordinated relationship at their institution (Danim, 2003). Shoya Zichy a woman who researched women's leadership, in her book Women and the Leadership Quotient, try to peel eight types of women's leadership, namely: the type of trustees (the trust), the type of conservator (which maintains), type tactician (which prioritizes tactics), the type of realistic (which prioritize realistic reality on the ground), the type of strategic (that promotes rational steps to control the situation), the type of innovator (that promotes innovations in solving the problem), the type of mentor (who put pressure on the motivation given to followers), and type advocator (which focuses on efforts to motivate followers with ideas or hints brilliant (Tilaar dan Widarto, 2003).

\section{CONCLUSION}

Women have the spirit, skills, and qualities that are not less than men. The only exception lies in the opportunities they get. When the opportunity came which was then combined with a fighting spirit, will bring women leaders are reliable because there is no difference of principle between the educational leadership abilities between men and women. The image of women as a person who also has the leadership capacity can be revitalized to bring back the gait struggles women figure very inspiring leadership. Islam is the most robust basis in pursuit of improving the condition of subordination of women, and not as a barrier to the advancement of women.

Educational leadership term containing two senses at once, which explains the nature of the leadership traits or how to organize, influence, and direct a person. While the object which explains the educational leadership is done. So the leadership of Islamic education is an activity guide, guide, guide and show the way towards reaching educational purposes pleasing to Allah SWT. So in this case, very clear orientation and goals to be achieved by the Islamic educational leadership towards the achievement of educational goals based on and the pleasure of Allah (Mardhatillah).

The requirement for an educational leader is that the educational leader must be able to lead the organization/ institution, is responsible for the achievement of the organization/ institution, is also expected to be a leader and innovator in organizations/institutions. It also must have the leadership skills and human relations skills and good leadership to implement the model following the characteristics of her, because the real success of an organization/ institution essentially lies in the efficiency and effectiveness of the appearance of a leader. Thus, in this case, both one's biological factor that men and women are not the main requirements in educational leadership. 


\section{REFERENCES}

Ahmad, Abi al-Husain Ibn Faris Zakariyya. 1989. Mu'jam Maqayis al-Lughah Juz II. t.tp: Dar al-Fikr.

Al-Bukhari, Shahih al-Bukhari, "fi al-Istiqrad wa Ada' al-Duyun wa al-Hijr wa al-Taflis, al-'Abd Ra'a fi Mali Sayyidih wa lam Ya'mal illa bi-Iznih", no. 2.232, juz II. hlm. 848.

Al-Hibri, Azizah, dkk. 2001. Perempuan dalam Masyarakat Indonesia. Yogyakarta: Sunan Kalijaga Press.

Anwar, Marzani, dkk. 2010. Modul Membangun Relasi Setara Antara Perempuan dan Laki-Laki Melalui Pendidikan Islam. Jakarta: Direktorat Jenderal Pendidikan Islam Kementrian Agama dengan dukungan AIBEP.

Bush,Tony \& Coleman, Marianne. 2006. Manajemen Strategis Kepemimpinan Pendidikan (Terj. Fahrurrozi). Jogjakarta: IRCiSoD.

Danim, S. 2003. Menjadi Komunitas Pembelajar: Kepemimpinan Transformasional dalam Komunitas Organisasi Pembelajaran. Jakarta: Bumi Aksara.

Diana, Ilfi Nur. 2008. Islam dan Kepemimpinan Perempuan di Ranah Politik: Egalita Jurnal Kesetaraan dan Keadlian Gender. Malang: PSG UIN Malang.

Fakih, Aunur Rahim, dkk. 2001. Kepemimpinan Islam. Yogyakarta: UII Press.

Kartono, Kartini. 1983. Pemimpin dan Kepemimpinan. Apakah Pemimpin Abnormal Itu? Jakarta: CV. Rajawali.

Mc. Clelland, David. Tt. Dorongan Hati Menuju Modernisasi. Dalam Weiner Myron. Modernisasi: Dinamika Pertumbuhan. New York: Voice of America Forum Lecture.

Naily, N. 2008. Nyai and Gender Awareness in Pesantren and Traditionalist Muslim Community in East Java. Australia: Unpublished thesis Australian National University.

Qardhawy, Yusuf. 1997. Fiqh Daulah Dalam Perspektif al-Qur'an dan Sunnah. Jakarta: Pustaka Al-Kautsar.

Salim, Abd. Muin. 2004. Konsepsi Kekuasaan Politik dalam al-Qur'an. Jakarta: Raja Grafindo Persada. 
Tan, Melly G. 1991. Perempuan Indonesia Pemimpin Masa Depan. Jakarta: Pustaka Sinar Harapan.

Tilaar, M. dan W.T. Widarto. 2003. Perempuan Pemimpin Indonesia. Jakarta: Gramedia Widiasarana.

Umar, Nasaruddin. 2001. Argumen Kesetaraan Gender Perspektif Al-Quran. Jakarta: Paramadina. 